\title{
VARIATION OF PHENOLIC ACIDS FROM HERB AND ROOTS OF SALSOLA KALI L.
}

\author{
ANNA SOKOŁOWSKA-KRZACZEK ${ }^{1}$, \\ KrYSTYNA SKALICKA-WOŹNIAK ${ }^{2}$, KATARZYNA CZUBKOWSKA ${ }^{1}$ \\ ${ }^{1}$ Department of Pharmaceutical Botany \\ ${ }^{2}$ Department of Pharmacognosy with Medicinal Plant Laboratory, \\ Medical University of Lublin \\ Chodźki 1, 20-093 Lublin, Poland \\ e-mail:kskalicka@pharmacognosy.org
}

(Received: March 11, 2009. Accepted: June 30, 2009)

\begin{abstract}
Qualitative and quantitative analysis of phenolic acids present as free and liberated from their conjunction with sugars and alcohols after hydrolysis in Salsola kali L was done, together with comparison of their content in roots and herb. Analysis was conducted by 2D-TLC and HPLC methods. Eleven phenolic acids were identified such as: protocatechuic, caffeic, gentisic, p-coumaric, p-hydroxybenzoic, p-hydroxyphenylacetic, syryngic, vanillic, ferulic, $\alpha$ - and $\beta$-resorcylic. Differences in composition of fraction of free phenolic acids and those liberated after hydrolysis were noticed. The amount of individual compounds were in the range between $0.10 \pm 0.04 \mathrm{mg} / 100 \mathrm{~g}$ of dry weight for p-OH-benzoic acid and $6.40 \pm 1.75 \mathrm{mg} / 100 \mathrm{~g}$ of dry weight for ferulic acid.
\end{abstract}

KEY WORDS: Salsola kali L., phenolic acids, Chenopodiaceae, TLC, HPLC.

\section{INTRODUCTION}

Salsola kali L. from Chenopodiaceae family (known as Russian thistle) is a halophytic plant occurring in Eurasia on sandy area. The name of the genus derived from the Latin - sallere means to salt, in reference to the salt tolerance plants (Reimann et al. 1995; Idzikowska 2005).

Members of this genus are found in most arid places of the world, along sea beaches, in grassland and desert communities. It easy vegetates on dry soil and is resistant to $\mathrm{pH}$ fluctuation and aggressive climate. All this caused that Salsola kali L. is cultivated in desert areas like Saudi Arabia, Kuwait, United Arab Emirates to prevent erosion of soils. In Poland the plant is characteristic for The Baltic seaside and it has been considered as a rare genus existing on the beaches, at the foot of dunes. Salsola kali L. can appear also inland under the rivers on sandy, saline soil (Bardziej 1972). In Polish flora Salsola kali L. is a representative of a rare group of plants, which are pulling out and spread by the wind on areas which are lack of arborescent plants. The dried plant can easily detach and become a tumbleweed. Seeds, held in the leaf axils, fall to the ground. One plant produces about 250000 seeds, which remain viable for less than a year (Young 1991). The seeds are eaten by at least eight species of granivorous birds. Russian-thistle is palatable to sheep and cattle from early spring until flowering, at which time sharp spines form, and again during winter when spines are softened by moisture (US Depart- ment 1937). In spring it provides fair nutrition for livestock and wildlife. The nutritional value of winter forage, after the plant has dried, is higher. It is a good source of vitamin A and phosphorus (Cook et al. 1954).

Salsola kali L. is an annual, pubescent plant. It is highly branched and rounded in form, growing from $0.3-1 \mathrm{~m}$ in height and from 0.3-1.5 $\mathrm{m}$ in diameter. Leaves are linearsubulate, acuminate. Hermaphrodite flowers have 2 conspicuous, ovate-triangular bracteoles with long spine-like apex, longer than the flowers. The small, winged seeds, retained in the leaf axils until after plant death and contain no endosperm tissue. The root system consists of a taproot and extensive lateral roots. Under crowded conditions, roots are shallow (Hitchcock and Cronquist 1964; Tutin 1968; Allen 1982).

Herb of Salsola kali L. contains small amount of isochinolin alkaloids: salsolin and salsolidin $(0.2 \%)$ and a lot of mineral salts (about $22.6 \%$, especially potassium, calcium, manganese, aluminium, iron) (Hegnauer 1964). Salsolin and salsolidin are effective in clinical treatment of hypertonia, posses sleep-inducing activity and tonifier on nervous system. One dose of salsolin $(0.03 \mathrm{~g}$ orally or $0.01 \mathrm{~g}$ subcutaneous) cause decreasing of blood pressure about 10-25 $\mathrm{mmHg}$ for 20-30 minutes (Borkowski and Wrociński 1959). Some fatty acids like linolenic, oleinic, arachidonic, palmitinic and stearinic were identified together with 4-desmethylsterols derivatives (Salt and Adler 1985). TLC analysis has shown the occurrence of triacetonamine and beta- 
ine (Karawya et al. 1971), also isorhamnetin 3-o-glucoside, 3-o-rutinosied, kempferol, quercetin and rhamnetin were identified (Tomas et al. 1985; Hegnauer 1989). Russian thistle as a plant rich in sodium was an important source of soda ash until the early 19th century as the alkali materials are essential to making glass, soap, and many other commodites (Tim 2006). The inhalation of Salsola kali L. pollen is an important cause of allergic respiratory symptoms in the West and Central states of the USA, in North Africa and in Mediterranean and some Arabic countries (Colás et al. 2005), but subcutaneous administration of a Salsola extract is safe and well tolerated (Grade et al. 2005).

Salsola richteri L. - another plant from Salsola genus, is an endemit component of semi-stabilized and fixed sand dunes in central Asia. Salsolin and salsolidin isolated from fruits and flowers of $S$. richteri $\mathrm{L}$. are used as drugs in Russia (as a hydrochloride) for treatment of high blood pressure and headache. Because in Poland fruits and flowers of $S$. richteri $\mathrm{L}$. are hard to reach, there are trials for its replacement with herb of $S$. kali.

Salsola was found to be an allelopathically active species, which decreases the growth of some selected associated species during its decaying process. Salsola is autotoxic, but its germination is not inhibited by any of the isolated phytotoxins applied. Some phenolic acids like caffeic, ferulic, chlorogenic, isochlorogenic, and neochlorogenic were identified among phytotoxins identified from Salsola kali L. leaves (Lodhi 1979). Phenolic acids are also very interesting from botanical and pharmacological points of view. First of all they can be implicated as an important regulatory molecule in plant defense. As accumulated in leaves and steams they protect plants by absorbing UV radiation, also protect them against pathogen infection, stimulate germination and growth (Dixon and Paiva 1995; Kopcewicz and Lewak 1998). From pharmacological and therapeutic points of view, the antioxidant properties of phenolic acids, such as free-radical scavenging and inhibition of lipid peroxidation, are the most crucial (Marimuthu et al. 2008). Radical scavenging activity of phenolic acids depends on the number and position of hydroxyl (-OH) and methoxy (-OCH3) substituents in the molecules. It has been also found that the derivatives of cinnamic acids are more active antioxidants than the derivatives of benzoic acid (Rice-Evans et al. 1996; Cai et al. 2006).

The aim of our study was qualitative and quantitative analysis of phenolic acids present as free and liberated from their conjunction with sugars and alcohols after hydrolysis. As far as we know preliminary examination of leaves let to identification of five phenolic acids (Lodhi 1979), so further experiments concerning qualitative and quantitative calculation of the content of that group of compounds seems to be very important.

\section{MATERIAL AND METHODS}

\section{Plant material}

Herb and roots of Salsola kali L. were collected from natural site in Józefów near Biłgoraj (Poland) in 2006. It was dried and fragmented according to the standards accepted by Polish Pharmacopoea. Samples of plant material are deposited in the Department of Pharmaceutical Botany, Medical University in Lublin.

\section{Extraction and isolation}

Dried and crushed plant material (220 g of herb and $18 \mathrm{~g}$ of roots) was extracted three times with $500 \mathrm{ml}$ of the mixture of methanol and water (8:2). Obtained extract was concentrated under reduce pressure and residue was diluted with hot water, cooled and placed in a refrigerator for 24 hours. After that time the participate was filtered off. Free phenolic acids fractions (A) were obtained according to Ibrahim and Towers (1960) and Krzaczek (1984). The filtrate was extracted with petroleum ether followed by diethyl ether. The combined etheric extract were dried with anhydrous sodium sulphate and evaporated.

The water fraction which has left was subjective to acid and alkaline hydrolysis in order to liberate acids presented as glycosides and esters respectively. Hydrolysis were performed according to Schmidtlein and Herrmann (1975). Fraction of phenolic acids liberated from their conjunction with sugars and alcohols were obtained (B).

\section{Thin-layer chromatography}

Two-dimensional chromatography was carried out according to Smolarz and Waksmundzka-Hajnos method (1993). TLC chromatography was performed on $100 \times 100 \times 0.1 \mathrm{~mm}$ plastic cellulose plates (E. Merck, Darmstadt, Germany) with application of DS horizontal chambers.

Before development, the plates were conditioned in the chambers for $5 \mathrm{~min}$ in the vapors above benzene - methanol - acetic acid (94:1:5 v/v/v) and then developed in the first direction benzene - methanol - acetic acid - acetonitrile $(80: 10: 5: 5 \mathrm{v} / \mathrm{v})$ and sodium formate - formic acid water $(10: 1: 200 \mathrm{w} / \mathrm{v} / \mathrm{v})$ in the second direction. After development in the first direction the eluent was completely evaporated by drying in air. Derivatisation was performed by spraying with $2 \%$ aqueous solution of ferric chloride $\left(\mathrm{FeCl}_{3}\right)$, diazotized sulfanilic acid (dSA) in $20 \%$ sodium carbonate solution and diazotized p-nitroaniline (pNA) for phenolic acids (Smolarz and Waksmundzka-Hajnos 1993).

\section{HPLC analysis}

HPLC experiments were carried out using Agilent HP 1100 chromatogram with Diode Array Detector, coupled with an auto-sampler and a column thermostat. A stainless column $(250 \times 4.6 \mathrm{~mm})$ packed with $5 \mu \mathrm{m}$ Hypersil BDS $\mathrm{C}_{18}$ (Shandon, UK) was used. The mobile phase were acetonitrile (B) and water with $1 \%$ acetic acid (A) in a stepwise gradient as follow: $0 \mathrm{~min}-10 \% \mathrm{~B}$ in $\mathrm{A}, 10 \mathrm{~min}-10 \%$ $\mathrm{B}$ in $\mathrm{A}, 15 \mathrm{~min}-20 \% \mathrm{~B}$ in $\mathrm{A}, 30 \mathrm{~min}-30 \% \mathrm{~B}$ in $\mathrm{A}, 35$ $\min -100 \%$ B in A 40 min $-100 \%$ B in A. The sample injection volume was $10 \mu \mathrm{L}$, the flow rate was $1 \mathrm{~mL} / \mathrm{min}$. The experiments were carried out at $25^{\circ} \mathrm{C}$. The identification was performed by comparing retention times and UV spectra with those analysed under the same conditions for appropriate standards. The quantitative determination was performed in $\lambda=254,280$ and $320 \mathrm{~nm}$ (Skalicka-Woźniak and Głowniak, 2008). Analyses were repeated three times and the SD (standard deviation) and RSD value (the percentage of relative standard deviation) were calculated.

\section{RESULTS AND DISCUSSION}

Fractions of free phenolic acids and those liberated from their conjunction with sugars and alcohols after acid and 
TABLE 1. The occurrence of phenolic acids in herb and roots of Salsola kali L.

\begin{tabular}{|c|c|c|c|c|c|}
\hline \multirow{2}{*}{ No } & \multirow{2}{*}{ Phenolic acids } & \multicolumn{2}{|c|}{ Herb } & \multicolumn{2}{|c|}{ Roots } \\
\hline & & A & B & A & B \\
\hline 1 & $\begin{array}{c}\text { protocatechuic } \\
\text { (3,4-dihydroxybenzoic) }\end{array}$ & + & + & - & + \\
\hline 2 & $\begin{array}{c}\text { caffeic (trans + cis) } \\
(3,4 \text {-dihydroxycinnamic) }\end{array}$ & + & + & - & + \\
\hline 3 & $\begin{array}{c}\text { gentisic } \\
(2,5 \text {-dioxybenzoic })\end{array}$ & - & + & - & + \\
\hline 4 & $\begin{array}{c}\text { p-coumaric } \\
\text { (4-hydroxycinnamic) }\end{array}$ & + & + & + & + \\
\hline 5 & $\begin{array}{c}\text { p-OH-benzoic } \\
\text { (4-hydroxybenzoic) }\end{array}$ & + & + & + & + \\
\hline 6 & $\begin{array}{l}\text { p-OH-phenylacetic } \\
\text { (benzeneacetic) }\end{array}$ & - & + & - & + \\
\hline 7 & $\begin{array}{c}\text { syryngic } \\
\text { (4-hydroxy-3,5-dimethoxybenzoic) }\end{array}$ & + & + & - & + \\
\hline 8 & $\begin{array}{c}\text { vanillic } \\
\text { (4-hydroxy-3-methoxybenzoic) }\end{array}$ & + & + & + & + \\
\hline 9 & $\begin{array}{c}\text { ferulic (trans }+ \text { cis }) \\
\text { (4-hydroxy-3-methoxycinnamic) }\end{array}$ & + & + & + & + \\
\hline 10 & $\begin{array}{c}\alpha \text {-resorcylic } \\
(3,5 \text {-dihydroxybenzoic) }\end{array}$ & + & + & - & + \\
\hline 11 & $\begin{array}{c}\beta \text {-resorcylic } \\
(2,4 \text {-dihydroxybenzoic) }\end{array}$ & - & + & - & + \\
\hline
\end{tabular}

alkaline hydrolysis from herb and roots of Salsola kali L. were analysed. Qualitative 2D-TLC and HPLC analysis

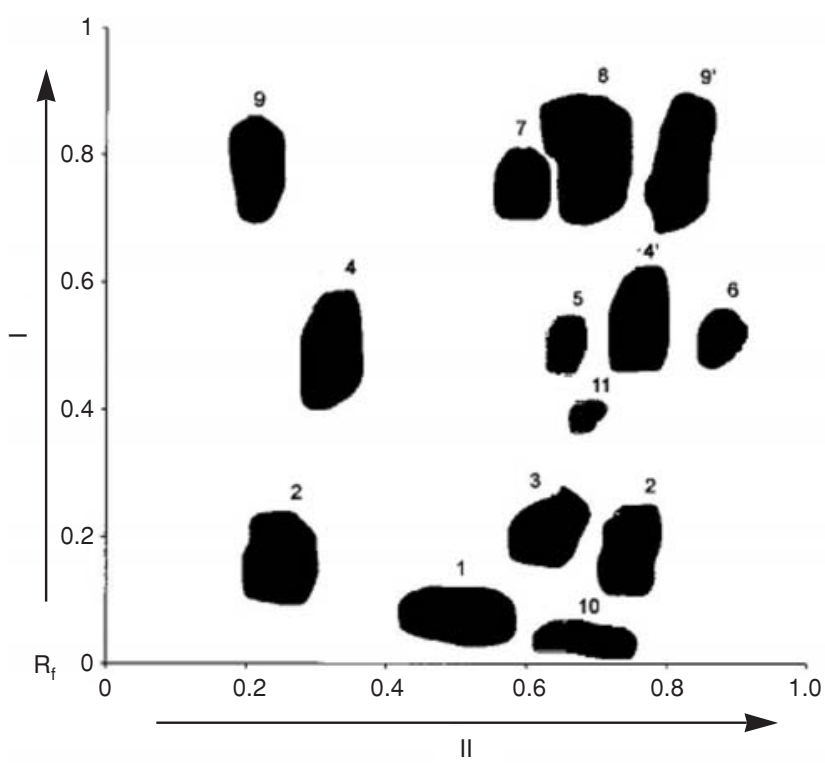

Fig. 1. The 2D-TLC chromatogram of phenolic acids from Salsola kali L. The numbers of spots refer to compounds listed in Table 1. The cis isomers are marked with an apostrophe.

was done. Results obtained after TLC analysis are presented in Table 1 and Figure 1. Figure 2 presents HPLC chromatograms of phenolic acids liberated after hydrolysis from roots of Salsola kali L.

Eleven phenolic acids were identified: protocatechuic, caffeic, gentisic, p-coumaric, p-hydroxybenzoic, p-hydroxyphenylacetic, syryngic, vanillic, ferulic, $\alpha$ - and $\beta$-resorcylic. All of them were found in herb and roots as liberated after hydrolysis. Gentisic, p-hydroxyphenylacetic and $\beta$-resorcylic acids were present only as glycosides or esters and cannot be identified as free in Salsola kali L. Additionally protocatechuic, caffeic, syryngic and $\alpha$-resorcylic acids were not detected in corresponding fraction from roots.

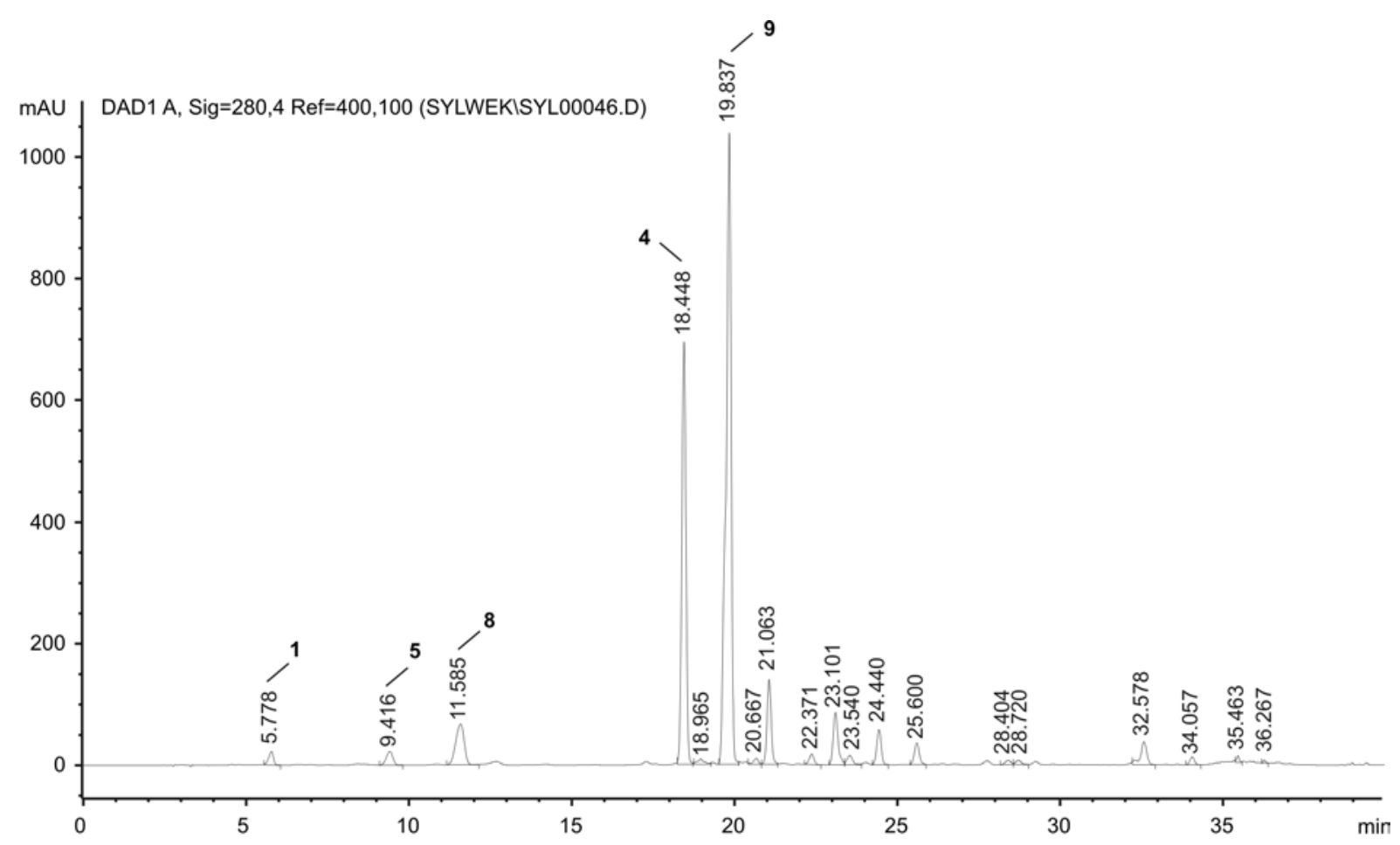

Fig. 2. HPLC chromatogram of phenolic acids liberated after acid and alkaline hydrolysis from roots of Salsola kali L. The numbers of spots refer to compounds listed in Table 1. 
TABLE 2. The content of major phenolic acids in Salsola kali L. (c=mg/100 g) together with SD and RSD values. Each value is from three replicate analyses. (SD standard deviation, RSD relative standard deviation, ND not detected).

\begin{tabular}{|c|c|c|c|c|c|c|}
\hline & & protocatechuic & p-OH-benzoic & p-coumaric & ferulic & vanillic \\
\hline \multirow{3}{*}{ S. kali herba A } & $\mathrm{c}$ & 0.17 & 0.25 & 0.55 & 0.82 & 0.84 \\
\hline & $\mathrm{SD}$ & 0.02 & 0.05 & 0.02 & 0.09 & 0.08 \\
\hline & RSD & 11.76 & 20.00 & 3.27 & 10.98 & 9.52 \\
\hline \multirow[b]{2}{*}{ S. kali root A } & $\mathrm{c}$ & & 0.10 & 0.11 & 0.11 & 0.26 \\
\hline & $\mathrm{SD}$ & ND & 0.04 & 0.02 & 0.03 & 0.05 \\
\hline \multirow{3}{*}{ S. kali root B } & $\mathrm{c}$ & 0.75 & 0.86 & 0.65 & 6.40 & 1.20 \\
\hline & $\mathrm{SD}$ & 0.11 & 0.16 & 0.19 & 1.75 & 0.12 \\
\hline & RSD & 14.67 & 18.14 & 29.23 & 27.34 & 10.00 \\
\hline \multirow[b]{2}{*}{ S. kali herba B } & $\mathrm{c}$ & 0.28 & 0.26 & 1.85 & 5.46 & 1.10 \\
\hline & $\mathrm{SD}$ & 0.01 & 0.04 & 0.31 & 0.21 & 0.01 \\
\hline
\end{tabular}

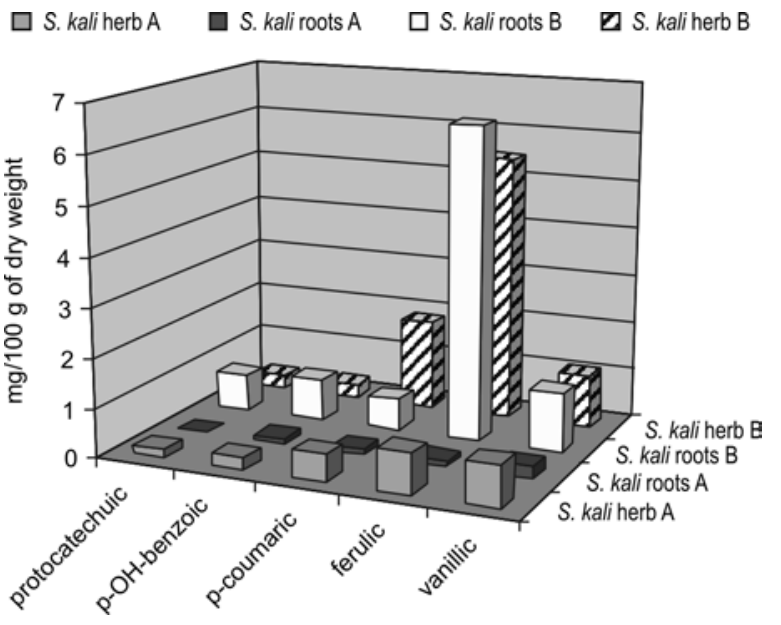

Fig. 3. The content of phenolic acids in Salsola kali L.

Accurate identification was performed on the basis of 2D-TLC method. HPLC method let for identification of only five phenolic acids such as protocatechuic, p-hydroxybenzoic, p-coumaric, ferulic and vanillic. Further analysis was not possible because of the lack of sufficient amount of standards.

In order to get to know the amount of each compounds HPLC quantitative experiments were performed. The calibration curves for all the standards were linear $\left(R^{2}=\right.$ 0.9991-0.9999) in a concentration range $0.01-2.00 \mathrm{mg} / 10$ $\mathrm{ml}$. The SD value was in the range of $0.01-1.75$ and RSD value as between 1.18-29.23. The amounts of phenolic acids detected in the analysed samples are shown in Table 2 and visualized on Figure 3.

The presence of ferulic and caffeic acid reported before was confirmed (Lodhi 1979). Ferulic and p-coumaric acids were identified in alcoholic extract from whole plant of Salsola collina (Xiang et al. 2007). In our experiment presence of ferulic, caffeic and p-coumaric acids was confirmed in herb and roots of Salsola kali and additionally nine more were identified together with their quantitative calculation.

It is easily seen that the content of phenolic acids in fractions liberated from their conjunction with sugars and alcohols after hydrolysis is much higher than in corresponding fractions containing free acids. The richest fraction was that obtained after liberation of acids from roots. Analogous fraction of free acids possesses lower concentration of every calculated compound. The amount of individual compounds are ranged between $0.10 \pm 0.04 \mathrm{mg} / 100 \mathrm{~g}$ for $\mathrm{p}$ -OH-benzoic acid and $6.40 \pm 1.75 \mathrm{mg} / 100 \mathrm{~g}$ of dry weight for ferulic acid.

Ferulic acid is the most abundant among analysed compounds. It is known for its strong anti-inflammatory, antithrombosis, anti-cancer and antibacterial activity. It also decreases the synthesis of cholesterol and level of lipids and protects against coronary disease. Because of these properties and its low toxicity, ferulic acid is now widely used in the food and cosmetic industries (Ou and Kwok 2004). Ferulic acid and other identified in Salsola kali L. are also known for its strong antioxidant activity. Further experiments in this subject are very important and should be conducted, especially because this kind activity was reported for leaves and flowers collected in Tunisia (Ksouri et al. 2008). Some very active phenolic compounds with strong scavenging activity were isolated from Salsola foeti$d a$ from Pakistan (Khan et al. 2003).

\section{LITERATURE CITED}

ALLEN E.B. 1982. Water and nutrient competition between Salsola kali and two native grass species (Agropyron smithii and Bouteloua gracilis). Ecology 63: 732-741.

BARDZIEJ E. 1972. Rozmieszczenie rodzaju Salsola L. w Polsce. Flora Geobotan. 18: 299-307.

BORKOWSKI B., WROCIŃSKI T. 1959. Porównanie działania hipotensyjnego salsoliny i salsolidyny oraz protoweratryn. Acta Polon. Pham. 16: 197-203.

CAI Y.Z., SUN M., XING J., LUO Q., CORKE H. 2006. Structure-radical scavenging activity relationships of phenolic compounds from traditional Chinese medicinal plants. Life Sci. 78: 2872-2888.

COLÁS C., MONZÓN S., VENTURINI M., LEZAUN A., LACLAUSTRA M., LARA S., FERNÁNDEZ-CALDAS E. 2005. Correlation between Chenopodiacea/Amaranthacea pollen counts and allergic symptoms in Salsola kali monosensitized patients. J. Invest. Allergol. Clin. Immunol. 15: 254-258.

COOK C.W., STODDART L.A., HARRIS L.E. 1954. The nutritive value of winter range plants in the Great Basin as determined with digestion trials with sheep. Bulletin 372. Logan, UT, Utah State University, Agricultural Experiment Station. pp. 56. 
DIXON R.A., PAIVA N.L. 1995. Stress-induced phenylpropanoid metabolism. Plant Cell 7: 1085-1097.

GRADE J., FERRER A., JOVER V., PAGAN J.A., ANDREU C., ABELLAN A., FELIX R., MILAN J.M., PAJARON M., HUESTAS A.J., LAVIN J.R., TORRE de la F. 2005. Tolerance of a Salsola kali extract standardized in biological units administered by subcutaneous route. Multicenter study. Allerg. Immunopath. 33:100-104.

HEGNAUER R. 1964. Chemotaxonomie der Pflanzen. Bd. III, Birkhauser Verlag Basel und Stuttgart.

HEGNAUER R. 1989. Chemotaxonomie der Pflanzen. Bd. VIII, Basel Boston-Berlin.

HITCHCOCK C.L., CRONQUIST A. 1964. Vascular plants of the Pacific Northwest. Part 2. Salicaceae to Saxifragaceae. Seattle, WA: University of Washington Press. pp. 597.

IBRAHIM R.K., TOWERS G.H. 1960. Identification by chromatography of plant phenolic acids. Arch. Biochem. Biophys. 87: 125-127.

IDZIKOWSKA K. 2005. Morphological and anatomical structure of generative organs of Salsola kali sp.. ruthenica (Iljin) Soo at the sem level. Acta Soc. Bot. Pol. 74: 99-109.

KARAWYA M.S., WASSEL G.M., RÜCKER G., BAGHDADI H.H., AHMED Z.F. 1971. Isolation of triacetonamine from Salsola tetrandra. Phytochemistry 10: 3303-3304.

KHAN K.M., MAHARVI G.M., ABBASKHAN A., HAYAT S., KHAN M.T.H., MAKHMOOR T., CHOUDHARY M.I., SHAHEEN F., ATTA-UR-RAHMAN. 2003. Three Tyrosinase Inhibitors and Antioxidant Compounds from Salsola foeti$d a$. Helv. Chim. Acta 86: 457-464.

KOPCEWICZ J., LEWAK S. 1998. The basis of plant physiology. Wydawnictwo Naukowe PWN, Warszawa. (in Polish)

KRZACZEK T. 1984. Fenolokwasy w różnych surowcach garbnikowych z rodziny Rosaceae. Farm. Pol. 40: 475-477.

KSOURI R., MEGDICHE W., FALLEH H., TRABELSI N., BOULAABA M., SMAOUI A., ABDELLY C. 2008. Influence of biological, environmental and technical factors on phenolic content and antioxidant activities of Tunisian halophytes. C. R. Biologies 331: 865-873.

LODHI M.K.A. 1979. Allelopathic potential of Salsola kali L. and its possible role in rapid disappearance of weedy stage during revegetation. J. Chem. Ecol. 5: 429-437.
MARIMUTHU P., WU C.L., CHANG H.T., CHANG S.T. 2008. Antioxidant activity of the ethanolic extract from the bark of Chamaecyparis obtusa var. Formosana. J. Sci. Food Agric. 88: 1400-1405.

OU S., KWOK K.C. 2004. Ferulic acid: pharmaceutical functions, preparation and applications in foods. J. Sci. Food Agric. 84: 1261-1269.

REIMAN C., BRACKLESS S.W. 1995. Salt tolerance and ion reaction of Salsola kali; differencec between spp. tragus (L.) nyman and spp. ruthenica (Illjin) Soo. New Physiol. 130: 37-45.

RICE-EVANS C.A., MILLER N.J., PAGANGA G. 1996. Structure-antioxidant activity relationships of flavonoids and phenolic acids. Free Radical Bio. Med. 20: 933-956.

SALT T.A., ADLER J.H. 1985. Diversity of sterol composition in the family Chenopodiaceae. Lipids 20: 594-601.

SCHMIDTLEIN H., HERMANN K. 1975. Quantitative analysis for phenolic acids by thin layer chromatography. J Chromatogr. 115: 123-126.

SKALICKA K., GŁOWNIAK K. 2008. Quantitative Determination of Phenolic Acids in Different Extracts Obtained From Fruits of Peucedanum alsaticum L. and Peucedanum cervaria (L.) Lap. Chromatographia 68: 85-90.

SMOLARZ H.D., WAKSMUNDZKA-HAJNOS M. Two-dimensional TLC of phenolic acids on cellulose. J. Planar Chromatogr., 6: 278-281.

TIM M.S., SHORTLAND A., MANIATIS Y. 2006. The composition of soda-rich and mixed alkali plants ashes used in production of glass. J. Archeol. Sci. 33: 1284-1292.

TOMAS F., MORENILLA A., BARBERAN F.A.T. 1985. Two flavonol glycosides from Salsola kali. Fitoterapia 56: 365-366.

TUTIN T.G., HEYWOOD V.H., BURGES N.A., MOORE D.M., VALENTINE D.H., WALTERS S.N., WEBB D.A., BALL P.W., CHATER A.O., FERGUSON I.K. 1968. Flora Europaea, Rosaceae to Umbelliferae. Cambridge Univeristy Press, Vol. I, p. 105.

U.S. Department of Agriculture, Forest Service. 1937. Range plant handbook. Washington, DC. pp. 532.

XIANG Y., LI Y.B., ZHANG J., LI P., YAO Y.Z. 2007. Studies on chemical constituents of Salsola collina. Zhongguo Zhongyao Zazhi 32: 409-413.

YOUNG J.A. 1991. Tumbleweed. Sci. American. 264: 82-87. 